\title{
Potential of two indigenous strains of entomopathogenic nematodes, (Steinernema feltiae and Heterorhabditis bacteriophora) against the tomato leafminer (TLM), Tuta absoluta (Meyrick) (Lepidoptera: Gelechiidae), under laboratory and greenhouse environmental bioassay
}

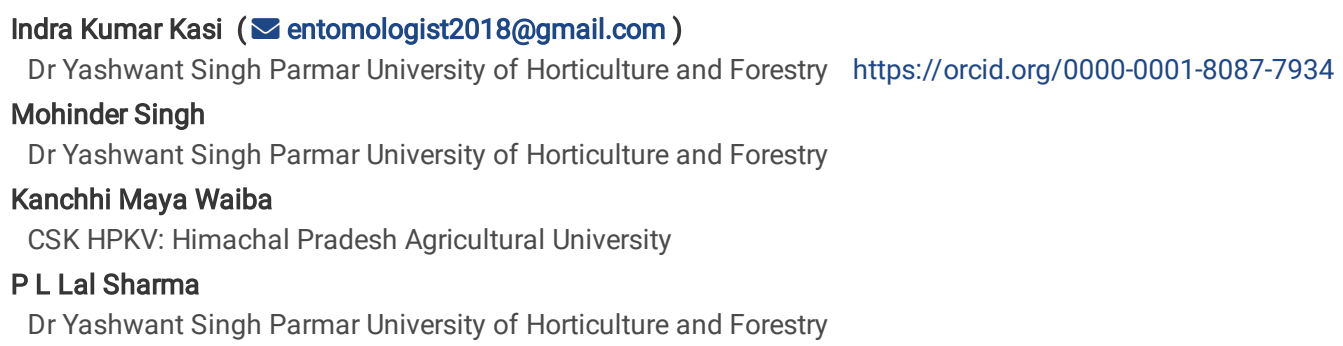




\section{Abstract}

The tomato leafminer (Tuta Absoluta) is an important pest of tomato crops which have features like; high reproductive potential, Invasive species are major threats to agronomic and natural ecosystems. Based on the pathogenicity of strains, only two isolates effectively show larvicidal activity. The native isolate was obtained from soil samples, collected from Rajgarh, Hamachi Pradesh, India. Petri dish bioassay use nematodes S. feltiae HR1 and H. bacteriophora HR2 species dose $\left(0,10,20,40,80,160 / \mathrm{IJs} / \mathrm{cm}^{2}\right)$. The (\%) 1 st instar larval mortality was ranged from 24.15 to $85.38 \%$. 2 nd instar from 29.87 to $90.00 \%$. $3 \mathrm{rd}$ instar from 24.15 to $90.00 \%$. 4th instar from 31.53 to $90.00 \%$ and pupae stage mortality was ranged from 31.53 to $85.38 \%$. Larvicidal activity after 48 - and 72 -hours exposure, the $S$. feltiae and $H$. bacteriophora $\left(1.0,1.30,1.60,1.90,2.20 / \mathrm{IJs} / \mathrm{cm}^{2}\right)$ showed potent larvicidal activity with $\mathrm{LC}_{50} \mathrm{LC}_{75}$ and $\mathrm{LC}_{90}$ of all instars and pupa show high mortality. The strain inhibits the larval and pupal development 48 to $72 \mathrm{hr}$ exposer time with $\mathrm{LC}_{50}$ range from 05.42 to $23.67, \mathrm{LC}_{75} 20.29$ to 83.12, LC $_{90} 16.52$ to 98.89 . Green house test is using the seam isolate of EPNs (HR1, HR2) on foliar application it caused by significant mortality results. These studies demonstrate the challenge for invasive species. The local indigenous strains of EPNs (S. feltiae HR1, H. bacteriophora HR2) as a good biocontrol agent against invasive pest of T. absoluta.

\section{Key Message}

- In the laboratory, the entomopathogenic nematode (EPN) Steinernema feltiae, and Heterorhabditis bacteriophora native isolate HR1, HR2, caused 90.00\% above mortality in T. absoluta.

- In the greenhouse EPN isolate are caused $95 \%$ mortality in Tuta absoluta $\mathrm{F}_{1}$ hybrid tomato crop plant.

- $\mathrm{LC}_{50}, \mathrm{LC}_{75}, \mathrm{LC}_{90}$ ranged between $23.67-83.12$ and $2.20 \mathrm{IJ} / \mathrm{cm}^{2}$ in a period of $48-72 \mathrm{~h}$.

- Under greenhouse conditions, a 3 foliar prying application of EPN with a mortality achieved significant \% mortality of $T$. absoluta.

- Additionally, native EPNs isolate have enormous potential for the control of foliage pests and may become a powerful alternative for T. absoluta control.

\section{Introduction}

Invasive species are important threats to the ecological and agricultural systems. Tomato leafminer (TLM), Tuta absoluta (Meyrick) (Lepidoptera: Gelechiidae), is native to South America. Outside its native place, the pest was detected for the first time in discovered in Spain in 2006 (Urbaneja et al., 2008 ), and since it quickly attacked 80 countries including India (CABI, 2018; CABI, 2020). The insect feeds on leaves, fruits, shoots, and apical shoots tomatoes can also cause 100 percent damage to plants in the absence of regulatory measures (Urbaneja et al., 2012; Balal et al., 2016; Biondi and Desneux, 2019). In India, the emergence of this insect was first carved with tomatoes in Pune and Bangalore in 2014 (Sridhar et al., 2014; Shashank et al., 2015), and since then it has spread to almost every part of the country tomato planting (Sridhar et al., 2014; Kalleshwaraswamy et al., 2015; Shashank et al., 2015; Balal et al., 2016; Sharma and Gavkare, 2017). In Himachal Pradesh, T. absoluta was first acquired in 2015 tomatoes in Nauni, Solan (Sharma and Gavkare, 2017). On problemsolving has emerged as a major threat to tomatoes in various parts of the state in open spaces and poly-houses. Previous reports indicate that in recent areas, T. absoluta quickly acquired a serious insect condition without drug abuse (Bielza, 2010; Desneux et al., 2010). Tuta absoluta control in particular based on pesticides and sometimes up to 14 times Insecticides while growing were needed (Campos et al., 2017; Han et al., 2019; Abbas et al., 2021; Waiba et al., 2021). Therefore, this insect is difficult to control chemically because the larvae live inside the mines and fruits where it is difficult to find pesticides. Biotic energy is high, spread speed again the ability to increase resistance to pesticides keeps pests at the bay challenge (Desneux et al., 2010; Ingegno et al., 2013; Roditakis et al., 2013; Roditakis et al., 2015). Invasive new invasive insect, tomato pinworm / small leaf, T. Absoluta was first recorded in Pune in a tomato plant that grew in a field and a thousand houses in 2014 and in southwestern India (Karnataka state) (ICAR 2015), and to our knowledge, there are no reports of this pest in eastern and northern and eastern India. Subsequently, the pest was reported on a farmer's farm in major tomato growing districts including Himachal Pradesh.

Entomopathogenic nematodes (EPNs) from the families Heterorhabditidae and Steinernematidae are soil organisms that bind to natural insects (Kaya and Gaugler 1993). These nematodes have evolved into interactions with bacteria in the genera Photorhabdus associated with Heterorhabditis spp., It is carried in the intestines of infectious hairs (IJs) (Bird and Akhurst 1983; Arthurs et al., 2004; Silva et al., 2002; Kasi et al., 2021). Xenorhabdus is connected to Steinernema spp. and is confined to a specific skin within the intestines of IJs. Nematodes receive their treatment by tracking insects (Lewis et al., 2006; Mansour and Biondi, 2021). After IJs have found a culprit, they infect it with an orifice such as the mouth, anus or edges or by entering the cuticle (especially in Heterorhabditis spp.). As soon as the IJs enter the host, they break down their outer cuticle (Sicard et al., 2004; Ben Husin and Port, 2021) and begin to absorb the hemolymph, causing the defiant to be released by extraction (Steinernema spp.) Or recurrence (Heterorhabditis spp.) (Martens et al., 2004; Martens and Goodrich-Blair 2005). The structure of nematodes - bacteria kill the host between 24 - 48h through septicemia or toxemia (Dowds and Peters 1971; Forst and Clarke 2002; Ndereyimana et al., 2020). Bacteria reminiscent of nematodes, which appear as IJs from extinct insect cadaver in search of new transmitters (Poinar 1990).

More than 100 species of EPNs have been identified worldwide (about $80 \%$ by steinernematid) and at least 13 of these species have been marketed (ShapiroIlan et al., 2014; Ndereyimana et al., 2019). In general, the natural violence against various insect species varies between EPN species. In addition, the differences between the types of EPNs in terms of demand management and tolerance of environmental conditions such as temperature and humidity may determine the field performance of EPNs (Martens et al., 2004; Noug, 2021). EPNs have been widely used in the control of economically important pests living in different habitats (Grewal et al., 2005; Susurluk, 2008). However, the formation of EPNs to delay the extinction or addition of supplements to increase leaf coverage and persistence of IJs have improved the use of EPNs in insect-infested animals (Williams and Walters 2000; Arthurs et al., 2004; Head et al., 2004; Kasi et al., 2021; Ben Husin and Port, 2021). 
The objective of the present study was to provide fundamental information necessary for the utilization of indigenously isolated EPNs as biological control agents. The study dealt with 2 nematode species such as S. feltiae and H. bacteriophora and their pathogenicity against Tuta absoluta under laboratory and greenhouse conditions.

\section{Materials And Methods}

A T. absoluta colony was maintained on tomato plants under greenhouse conditions. The colony had been established from larvae collected in September 2020 from the vegetable science department form the tomato greenhouse in UHF, HP, India, that used S. feltiae and H. bacteriophora (Poinar) for the pest's management.

\section{Rearing of tomato pinworm, Tuta absoluta}

TLM larvae and pupae were collected in a place that holds full heat greenhouse. T. Absoluta was raised in a nursery greenhouse (Roditakis et al., 2013), at 26 $\pm 2{ }^{\circ} \mathrm{C}, 60 \pm 10 \% \mathrm{RH}$, and L: D 8:16 photoperiod. These insects are grown in wooden cages covered with 80 mesh organdy cloth on tomato plants (S. Lycopersicum L.). Adults are fed $10 \%$ of the sugar solution in the oviposition cage.

\section{Source of entomopathogenic nematodes}

Two isolates of $S$. feltiae and $H$. bacteriophora were used in this study. The native isolate was obtained from soil samples, collected from Rajgarh, Hamachi Pradesh, India, using G. mellonella larvae as nematode traps. This isolate was cultured based on the method describe (Woodring and Kaya 1988 ) at $21 \pm 1{ }^{\circ} \mathrm{C}$ on the last instar larvae of $\mathrm{G}$. mellonella. Infective juveniles (IJs) that emerged during the first ten days were collected from white traps stored at $4{ }^{\circ} \mathrm{C}$ in distilled water for up to 14 days (Woodring and Kaya 1988). The nematodes were acclimatized at room temperature for about 30 min before being used in the experiments.

\section{Effect of Nematode Concentration}

Bioassays was performed in a petri dish $(9 \mathrm{~cm}$ ). Each unit is filled with 20 grams of sandy loam (Table 1). Soil moisture was adjusted to $7 \%$ (w / w). IJs were applied evenly on the sterilized sand surface at $0,5,10,20,40,80$, and $160 \mathrm{lJs} / \mathrm{cm} 2$ in $1 \mathrm{ml}$ of distilled water. Final sand moisture $10 \%$ (w / w). Ten t in each instar. The containers were kept at room temperature for $1 \mathrm{~h}$ before placing the entire larvae on the soil surface. There are four replicas for each concentration. Under controlled conditions the containers were kept in the growth chamber for $72 \mathrm{~h}$, after which the larvae were separated from the surface through a fine sieve and held individually under controlled conditions until adulthood. Three days later, $25 \%$ of the dead larvae were randomly selected and dissected under a stereomicroscope to confirm nematode infection. The experiment was performed twice.

\section{Larvicidal activity}

Each nematode species was added at different concentrations $\left(1.00,1.30,1.60,1.90,2.20 / \mathrm{mL}^{-1}\right)$ into the $9 \mathrm{~cm}$ petri dish in triplicate with $2 \mathrm{ml}$ of dechlorinated sterile water and 60 larvae of tested Tuta absoluta strains. The larvae were provided with young tomato leaves. One Petri plate without EPNs suspension was used as a control. After 24,48 , and $72 \mathrm{hr}$ the number of dead larvae was calculated. The strains that killed more than $50 \%$ of the larvae were considered pathogenic (Morton and Garcia-del-Pino 2009; Kasi et al., 2021). Two nematode isolates were examined quantitatively for larvicidal activity against $T$. absoluta, using various concentrations of EPNs suspensions. The infected larvae were observed under a stereo zoom microscope for each concentration at $72 \mathrm{~h}$ exposure time.

\section{Greenhous condition experimental fields}

\section{Study Site Selection}

The experimental farm is located at an elevation of $1260 \mathrm{~m}$ above mean sea level with $30^{\circ} 52^{\prime} \mathrm{N}$ latitude and $77^{\circ} 11^{\prime} \mathrm{E}$ longitude with East-West orientation of poly-house which represents the mid-hill zone of Himalayas, HP, India. This is an ideal location for poly-house with various features like single door, side, and top vent, drip irrigation, fogging facility, and internal shading with $50 \%$ green agro UV stabilized shade net.

\section{Experimental material and layout plan}

The tomato germplasm commercial market, $F_{1}$ Hybrid (BSS-816) were evaluated under a naturally ventilated poly-house having a $200 \mathrm{~m}^{2}$ area. The experiment was conducted in a randomized block design (RBD) with four replications inside the modified naturally ventilated polyhouse $(25 \mathrm{~m} \times 10 \mathrm{~m})$. Ten plants of the hybrid were planted at a spacing of $70 \times 30 \mathrm{~cm}$ and trained on two stems in each replication.

\section{Treatments}

Table 1 Treatments used in the field experiment to control Tuta absoluta (M.) 


\begin{tabular}{|c|c|c|}
\hline Designation & Treatment description & Type of treatment \\
\hline Native strain & S. feltiae & Entomopathogenic nematode \\
\hline $\mathrm{T}_{1}$ & $1,00,000 / \mathrm{IJ} ' \mathrm{~s} / \mathrm{m}^{-2}$ & Entomopathogenic nematode \\
\hline $\mathrm{T}_{2}$ & $2,00,000$ / IJ's / m² & Entomopathogenic nematode \\
\hline $\mathrm{T}_{3}$ & $4,00,000$ / IJ's / m ${ }^{-2}$ & Entomopathogenic nematode \\
\hline Native strain & H. bacteriophora & \\
\hline $\mathrm{T}_{4}$ & $1,00,000$ / IJ's / m² & Entomopathogenic nematode \\
\hline $\mathrm{T}_{5}$ & $2,00,000 / \mathrm{IJ}^{\prime} \mathrm{s} / \mathrm{m}^{-2}$ & Entomopathogenic nematode \\
\hline $\mathrm{T}_{6}$ & $4,00,000 / \mathrm{IJ}^{\prime} \mathrm{s} / \mathrm{m}^{-2}$ & Entomopathogenic nematode \\
\hline $\mathrm{T}_{7}$ & & \\
\hline
\end{tabular}

\section{Statistical Analysis}

Insect mortality was control-corrected (Abbott 1925) and Arcsine transformed when required to meet assumptions of normality and homogeneity of variances. In all experiments, control-corrected mortality was subjected to one-factor analysis of variance (ANOVA)

$$
\text { (\% mortality in treatment-\% mortality in control) }
$$

Corrected mortality $(\%)=--\longrightarrow 100$

$$
100 \text { - \% mortality in the control }
$$

The corrected percent mortality data thus obtained for different concentrations of Tuta absoluta (M.) at different concentrations were subjected to probit analysis as per the method given (Finney 1971). Concentration-mortality response data was conducted. Also, LSD $(P<0.05)$ values were calculated to differentiate means among treatments.

\section{Results}

\section{Petri dish bioassay of Tuta absoluta life stages}

bioassay of T. absoluta ( $1^{\text {st }}$ instar)

The results revealed that the $1^{\text {st }}$ instars larvae of the tomato leafminer were highly susceptible to two nematode species tested. After $72 \mathrm{~h}$ of treatment, there was an increase in (\%) larval mortality in all treatments. The (\%) larval mortality was ranged from 24.15 to $85.38 \%$ (Fig 1 ). The highest \% larval mortality was recorded in treatment with $H$. bacteriophora at $160 \mathrm{IJs} / \mathrm{cm}^{2}$ were $85.38 \%$ larval mortality was followed by S. feltiae at $160 \mathrm{IJs} / \mathrm{cm}^{2}(80.76 \%)$. The next best treatments in order of their efficacies were H. bacteriophora at $80 \mathrm{IJs} / \mathrm{cm}^{2}(67.47 \%)$, S. feltiae at $80 \mathrm{IJs} / \mathrm{cm}^{2}(63.78 \%)($ Fig 1$)$.

bioassay of T. absoluta ( $2^{\text {nd }}$ instar):

There was no larval mortality observed in the untreated control. The (\%) larval mortality was ranged from 29.87 to $90.00 \%$. After $72 \mathrm{~h}$ of treatment, the treatment $S$. feltiae at $160 \mathrm{IJs} / \mathrm{cm}^{2}(90.00 \%)$ recorded the highest larval mortality of $2^{\text {nd }}$ instars $T$. absoluta larvae and was found to be the most superior treatment. Which was followed by $H$. bacteriophora at $160 \mathrm{IJs} / \mathrm{cm}^{2}(80.76 \%)$. The next best treatments in order of their efficacies were $S$. feltiae at $80 \mathrm{IJs} / \mathrm{cm}^{2}$ (78.73\%), H. bacteriophora at $80 \mathrm{lJs} / \mathrm{cm}^{2}$ (72.08\%). The (\%) larval mortality was ranged from 24.15 to $90.00 \%$ (Fig 2).

bioassay of T. absoluta ( $3^{\text {rdt }}$ instar):

Recorded highest larval mortality of $3^{\text {rd }}$ instars $T$. absoluta larvae and found superior treatment. The highest percent larval mortality was recorded in treatment with $H$. bacteriophora at $160 \mathrm{IJs} / \mathrm{cm}^{2}$ were $90.00 \%$ larval mortality was recorded which was followed by S. feltiae at $160 \mathrm{IJs} / \mathrm{cm}^{2}(85.38 \%)$. The next best treatments in order of their efficacies were H. bacteriophora at $80 \mathrm{IJs} / \mathrm{cm}^{2}(74.12 \%)$, S. feltiae at $80 \mathrm{IJs} / \mathrm{cm}^{2}(69.50 \%)(\mathrm{Fig} 3)$.

bioassay of T. absoluta ( $4^{\text {th }}$ instar):

The (\%) larval mortality was ranged from 31.53 to $90.00 \%$. Recorded highest larval mortality of $4^{\text {th }}$ instars $T$. absoluta larvae and found to be most superior treatment. The highest percent larval mortality was recorded in treatment with $S$. feltiae at $160 \mathrm{JJ} / \mathrm{cm}^{2}$ were $90.00 \%$ larval mortality was recorded which was 
followed by $H$. bacteriophora at $160 \mathrm{IJs} / \mathrm{cm}^{2}(80.76 \%)$ (Fig 4). The next best treatments in order of their efficacies were $S$. feltiae at $80 \mathrm{IJs} / \mathrm{cm}^{2}$ (74.12\%), $H$. bacteriophora at $80 \mathrm{IJs} / \mathrm{cm}^{2}$ (67.84\%) (Fig 4).

bioassay of T. absoluta (Pupa):

The (\%) larval mortality was ranged from 31.53 to $85.38 \%$. Recorded highest larval mortality of pupae stage of $T$. absoluta larvae and found to be most superior treatment. The highest \% larval mortality was recorded in treatment with $H$. bacteriophora at $160 \mathrm{lJs} / \mathrm{cm}^{2}(85.38 \%)$ larval mortality was recorded which was followed by S. feltiae at $160 \mathrm{JJs} / \mathrm{cm}^{2}$ were $80.76 \%$. The next best treatments in order of their efficacies were $\mathrm{H}$. bacteriophora at $80 \mathrm{IJs} / \mathrm{cm}^{2}$ (69.50\%), S. feltiae at $80 \mathrm{IJs} / \mathrm{cm}^{2}$ (67.47\%) (Fig 5).

\section{Bioassay of larvicidal activity}

A toxicity assay was conducted to estimate the lethal concentration of entomopathogenic nematodes to following:

Larvicidal activity $\left(1^{\text {st }}\right.$ instar $)$

$1^{\text {st }}$ instar larvae of Tuta absoluta. The $\mathrm{LC}_{50}, \mathrm{LC}_{75}$ and $\mathrm{LC}_{90}$ for the $S$. feltiae $\left(1.0,1.30,1.60,1.90,2.20 / \mathrm{IJs}_{\mathrm{cm}}{ }^{2}\right)$, H. bacteriophora $(1.0,1.30,1.60,1.90$, $\left.2.20 / \mathrm{IJs} / \mathrm{cm}^{2}\right), 1^{\text {st }}$ instar for $48 \mathrm{~h}$ were evaluated as $\mathrm{LC}_{50}$ of $13.29 \mu \mathrm{g} \mathrm{mL}^{-1}, 23.67 \mathrm{IJs} / \mathrm{cm}^{2}$ and $\mathrm{LC}_{75}$ of IJs/ $\mathrm{cm}^{2}, 75.64 \mathrm{IJs} / \mathrm{cm}^{2}, 78.77 \mathrm{IJs} / \mathrm{cm}^{2}$, and LC 90 of $\mathrm{IJs} / \mathrm{cm}^{2}, 31.64 \mathrm{IJs} / \mathrm{cm}^{2}, 32.46 \mathrm{IJs} / \mathrm{cm}^{2}$ respectively. For $72 \mathrm{~h}$ exposure (Fig 6), LC 50 of $14.08 \mathrm{lJs} / \mathrm{cm}^{2}, 15.94 \mathrm{IJs} / \mathrm{cm}^{2}, \mathrm{LC}_{75} \mathrm{of} 46.54 \mathrm{IJs} / \mathrm{cm}^{2}, 42.58 \mathrm{IJs} / \mathrm{cm}^{2}$ and $\mathrm{LC}_{90}$ of $16.52 \mathrm{IJs} / \mathrm{cm}^{2}, 10.07 \mathrm{IJs} / \mathrm{cm}^{2}$ (Table 1$)$.

Larvicidal activity $\left(2^{\text {nd }}\right.$ instar $)$

$2^{\text {nd }}$ instar larvae of Tuta absoluta, for $48 \mathrm{~h}$ were evaluated as $\mathrm{LC}_{50}$ of $14.27 \mathrm{IJs} / \mathrm{cm}^{2}, 13.47 \mathrm{IJs} / \mathrm{cm}^{2}$ and LC 75 of IJs/cm ${ }^{2}, 48.42 \mathrm{IJs} / \mathrm{cm}^{2}, 55.26 \mathrm{IJs} / \mathrm{cm}^{2}$, and $\mathrm{LC}_{90}$ of $\mathrm{IJs} / \mathrm{cm}^{2}, 45.40 \mathrm{IJs} / \mathrm{cm}^{2}, 96.81 \mathrm{IJs} / \mathrm{cm}^{2}$, respectively. For $72 \mathrm{~h}$ exposure (Fig 7), $\mathrm{LC}_{50}$ of $07.05 \mathrm{IJs} / \mathrm{cm}^{2}, 07.61 \mathrm{IJs} / \mathrm{cm}^{2}, \mathrm{LC}_{75}$ of $22.85 \mathrm{IJs} / \mathrm{cm}^{2}, 29.39$ $\mathrm{IJs} / \mathrm{cm}^{2}$ and $\mathrm{LC}_{90}$ of $65.81 \mathrm{IJs} / \mathrm{cm}^{2}, 65.14 \mathrm{IJs} / \mathrm{cm}^{2}$ (Table 1$)$.

Larvicidal activity ( $3^{\text {rd }}$ instar)

$3^{\text {rd }}$ instar larvae of Tuta absoluta, for $48 \mathrm{~h}$ were evaluated as $\mathrm{LC}_{50}$ of $19.29 \mathrm{IJs} / \mathrm{cm}^{2}, 08.55 \mathrm{IJs} / \mathrm{cm}^{2}$ and LC 75 of IJs/cm², $83.12 \mathrm{IJs} / \mathrm{cm}^{2}, 40.47 \mathrm{IJs} / \mathrm{cm}^{2}$, and $\mathrm{LC}_{90}$ of $\mathrm{IJs} / \mathrm{cm}^{2}, 50.44 \mathrm{IJs} / \mathrm{cm}^{2}, 98.89 \mathrm{IJs} / \mathrm{cm}^{2}$, respectively. For $72 \mathrm{~h}$ exposure (Fig 8), $\mathrm{LC}_{50}$ of $07.52 \mathrm{IJs} / \mathrm{cm}^{2}, 05.42 \mathrm{lJs} / \mathrm{cm}^{2}, \mathrm{LC}_{75}$ of $25.42 \mathrm{IJs} / \mathrm{cm}^{2}, 20.70$ $\mathrm{IJs} / \mathrm{cm}^{2}$ and $\mathrm{LC}_{90}$ of $26.03 \mathrm{IJs} / \mathrm{cm}^{2}, 69.19 \mathrm{IJs} / \mathrm{cm}^{2}$ (Table 1$)$.

Larvicidal activity $\left(4^{\text {th }}\right.$ instar)

$4^{\text {th }}$ instar larvae of Tuta absoluta, for $48 \mathrm{~h}$ were evaluated as $\mathrm{LC}_{50}$ of $09.32 \mathrm{IJs} / \mathrm{cm}^{2}, 13.90 \mathrm{IJs} / \mathrm{cm}^{2}$ and LC 75 of IJs/cm², $48.17 \mathrm{IJs} / \mathrm{cm}^{2}, 60.10 \mathrm{IJs} / \mathrm{cm}^{2}$, and

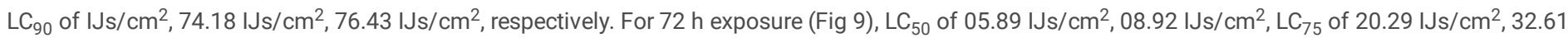
$\mathrm{IJs} / \mathrm{cm}^{2}$ and $\mathrm{LC}_{90}$ of $61.71 \mathrm{IJs} / \mathrm{cm}^{2}, 56.63 \mathrm{IJs} / \mathrm{cm}^{2}$ (Table 1$)$.

Larvicidal activity (Pupae stage)

Pupae of Tuta absoluta, for $48 \mathrm{~h}$ were evaluated as $\mathrm{LC}_{50}$ of $09.10 \mathrm{IJs} / \mathrm{cm}^{2}, 13.90 \mathrm{IJs} / \mathrm{cm}^{2}$ and LC 75 of $\mu \mathrm{g} \mathrm{mL}-1,41.75 \mathrm{IJs} / \mathrm{cm}^{2}, 60.10 \mathrm{IJs} / \mathrm{cm}^{2}$, and LC 90 of $\mathrm{IJs} / \mathrm{cm}^{2}, 78.47 \mathrm{IJs} / \mathrm{cm}^{2}, 98.43 \mathrm{IJs} / \mathrm{cm}^{2}$, respectively. For $72 \mathrm{~h}$ exposure (Fig 10),

\section{Table 1.}

Log probit analysis of larvicidal activity of tested nematode strain against tomato pinworm Tuta absoluta larvae instars and pupa stage 


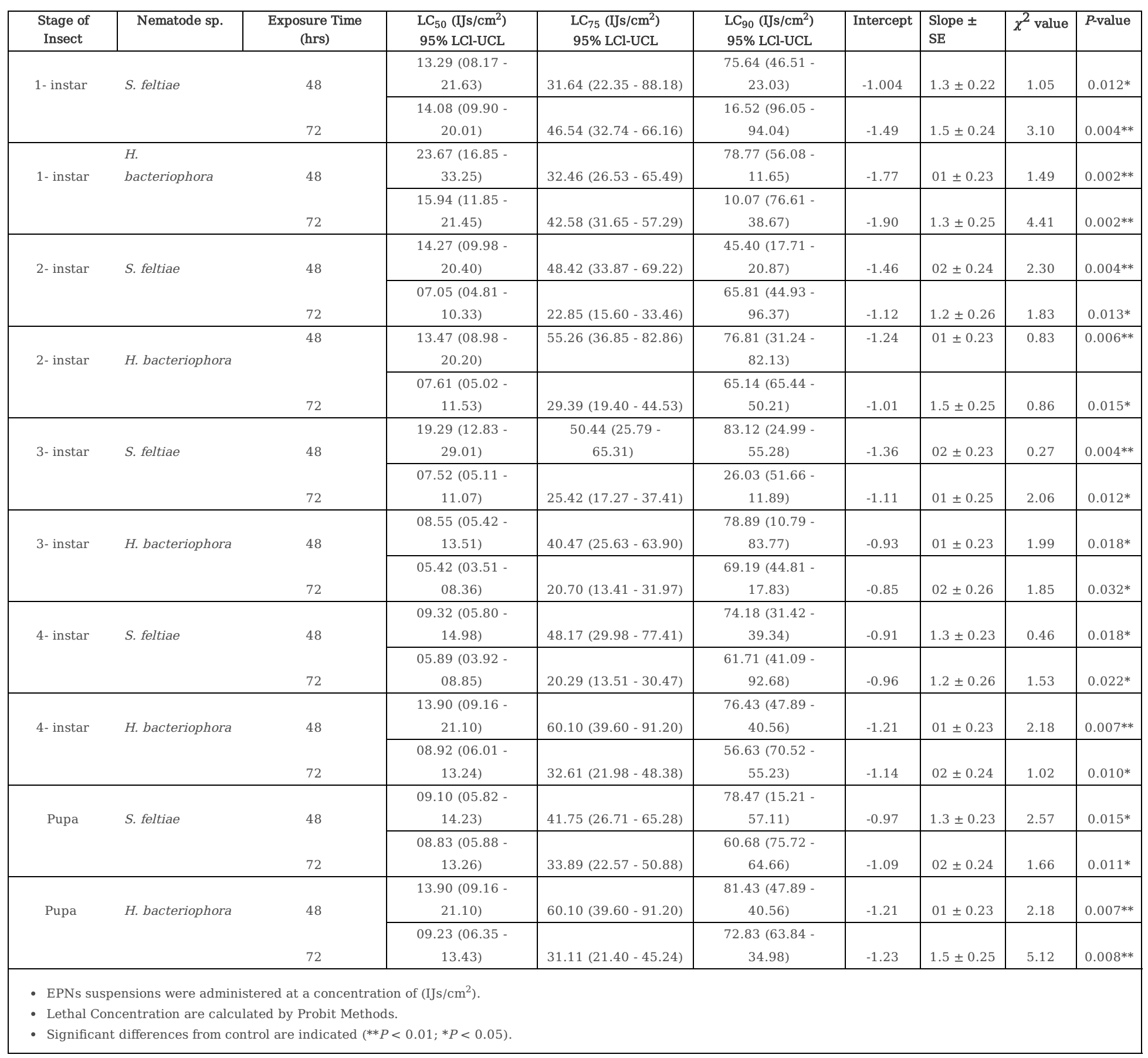

$-\mathrm{LC}_{50}$ of $08.83 \mathrm{IJs} / \mathrm{cm}^{2}, 09.23 \mathrm{IJs} / \mathrm{cm}^{2}, \mathrm{LC}_{75}$ of $33.89 \mathrm{IJs} / \mathrm{cm}^{2}, 31.11 \mathrm{IJs} / \mathrm{cm}^{2}$, and $\mathrm{LC}_{90}$ of $60.68 \mathrm{IJs} / \mathrm{cm}^{2}, 72.83 \mathrm{IJs} / \mathrm{cm}^{2}$ were noted by using (OPSTAT) software, the best larvicidal activity was obtained during the $72 \mathrm{~h}$ of exposure. The $S$. feltiae and H. bacteriophora, strains showed potent larvicidal activity with low concentration even at 48 and $72 \mathrm{~h}$ of exposure to compare other strains (Table 1).

The mortality was determined through different concentrations for both 48 and $72 \mathrm{~h}$ exposure. The mortality rate depends on the concentration and exposure time. However, the highest mortality range was observing H. bacteriophora treatment at very low concentrations for 48 and $72 \mathrm{~h}$. Even though S. feltiae showed slow mortality in 48 and $72 \mathrm{~h}$ exposure time, they restrained the larval development at the early pupal stage.

\section{Efficacy of EPNs against $T$. absoluta in greenhouse condition}

Data pertaining to the survival population of tomato leafminer Tuta absoluta on tomato one day before and $3^{\text {rd }}, 7^{\text {th }} 10^{\text {th }}$ and $14^{\text {th }}$ days after first spray was presented in (Table 2). The mean survival population of $T$. absoluta larvae one day before spray was ranged from 5.77 to 7.36 larvae/ plant. The pre-treatment data was found to be non-significant indicating the uniformity population of pest throughout the experimental plot. At $14^{\text {th }}$ days of first spray slight increase in the larval population was observed in all the treated plots. The mean number survival populations of larvae were ranged from 1.31 to 2.13 larvae/plant. In untreated control plot it was recorded highest 4.09 larvae/plant. The treatment with $H$. bacteriophora at 1,00,000 IJ's/ $\mathrm{cm}^{2}(1.31$ larvae/plant) was found be consistently effective against $T$. absoluta followed by H. bacteriophora at 2,00,000 IJ's/ $\mathrm{cm}^{2}(1.42$ larvae/plant) which were found to be equally effective. 
Treatment with $S$. feltiae at $1,00,000 \mathrm{IJ}$ 's $/ \mathrm{cm}^{2}$ (1.59 larvae/plant), $S$. feltiae at 2,00,000 IJ's/ $\mathrm{cm}^{2}$ (1.68 larvae/plant) which were the next in order of their efficacy and significant differences did not existed in remaining treatments.

Thus, overall results on efficacy indicated that $H$. bacteriophora at $1,00,000 \mathrm{IJ}$ 's $/ \mathrm{cm}^{2}$ (1.78 larvae/plant) was the most effective compared to other treatments in reducing the survival population of $T$. absoluta. The treatment with $S$. feltiae at $1,00,000 \mathrm{IJ}$ 's $/ \mathrm{cm}^{2}(1.97$ larvae/plant) was the next best effective treatment. Followed by $\mathrm{H}$. bacteriophora at $2,00,000 \mathrm{IJ}$ s/ $\mathrm{cm}^{2}$ (2.00 larvae/plant) were next in order of efficacy. At $14^{\text {th }}$ days of second spray slight increase in the larval population was observed in all the treated plots. The mean number survival populations of larvae were ranged from 1.18 to 1.51 larvae/plant. In untreated control plot it was recorded highest 4.24 larvae/plant. The treatment with $H$. bacteriophora at 2,00,000 IJ's/ $\mathrm{cm}^{2}(1.18 \mathrm{larvae} / \mathrm{plant})$ was found be consistently effective against $T$. absoluta followed by $S$. feltiae at 2,00,000 IJ's/ $\mathrm{cm}^{2}$ (1.38 larvae/plant) which were found to be equally effective. Treatment with $H$. bacteriophora at $1,00,000 \mathrm{IJ}$ 's $/ \mathrm{cm}^{2}$ (1.45 larvae/plant), $H$. bacteriophora at $4,00,000 \mathrm{IJ}$ 's $/ \mathrm{cm}^{2}(1.48$ larvae/plant) which were the next in order of their efficacy and significant differences did not existed in remaining treatments.

Thus the overall performance of the treatments indicated that the treatment with $\mathrm{H}$. bacteriophora at 2,00,000 IJ's/ $\mathrm{cm}^{2}$ (1.60 larvae/ plant) was found most superior over $H$. bacteriophora at $1,00,000 \mathrm{IJ}$ 's $/ \mathrm{cm}^{2}$ (1.66 larvae/plant), H. bacteriophora at 4,00,000 IJ's/cm ${ }^{2}(1.77$ larvae/plant). Treatments with $S$. feltiae at $1,00,000 \mathrm{IJ}$ 's $/ \mathrm{cm}^{2}$ (1.84 larvae/plant), S. feltiae at 2,00,000 IJ's/ $\mathrm{cm}^{2}$ (1.85 larvae/plant), S. feltiae at 4,00,000 IJ's/cm ${ }^{2}$ (2.06 larvae/plant) were found equally effective in reducing the $T$. absoluta population. At $14^{\text {th }}$ days of third spray slight increase in the larval population was observed in all the treated plots. The mean number survival populations of larvae were ranged from 1.02 to 1.98 larvae/plant. In untreated control plot it was recorded highest 4.92 larvae/plant. The treatment with $H$. bacteriophora at 4,00,000 IJ's/ $\mathrm{cm}^{2}$ (1.02 larvae/plant) was found be consistently effective against $T$. absoluta followed by $H$. bacteriophora at $2,00,000 \mathrm{IJ}$ 's $/ \mathrm{cm}^{2}$ (1.09 larvae/plant) which were found to be equally effective. Treatment with $S$. feltiae at 2,00,000 IJ's/cm ${ }^{2}(1.17$ larvae/plant), $S$. feltiae at $1,00,000 \mathrm{IJ}$ 's $/ \mathrm{cm}^{2}$ (1.34 larvae/plant) and $S$. feltiae at 4,00,000 IJ's/ $\mathrm{cm}^{2}$ (1.53 larvae/plant), H. bacteriophora at 1,00,000 IJ's/cm ${ }^{2}$ (1.98 larvae/plant) were found to be equally effective. However, the treatments with respectively as compared to 4.92 larvae/ plant in untreated control.

Thus, overall performance of the various treatments after third spray found that treatment with $\mathrm{H}$. bacteriophora at $4,00,000 \mathrm{IJ}$ 's $/ \mathrm{cm}^{2} \mathrm{proved}$ to be consistently most effective and superior over rest of the treatments and recorded the lowest larval population (1.17 larvae/ plant) compared to 4.48 larvae/plant recorded in untreated control. Treatment with $H$. bacteriophora at 2,00,000 IJ's/ $\mathrm{cm}^{2}(1.34$ larvae/plant), was next best treatment in the order of efficacy. Significant differences do not exist among the treatments with $S$. feltiae at 2,00,000 IJ's/ $\mathrm{cm}^{2}(1.60 \mathrm{larvae} / \mathrm{plant})$ and $S$. feltiae at 4,00,000 IJ's/cm ${ }^{2}(1.65 \mathrm{larvae} / \mathrm{plant})$ were found on par with each other. Whereas, the treatments with $S$. feltiae at 1,00,000 IJ's/ $\mathrm{cm}^{2}\left(1.83\right.$ larvae/plant), and $H$. bacteriophora at $2,00,000 \mathrm{IJ}$ 's/cm ${ }^{2}$ (2.25 larvae/ plant) were found moderately effective in reducing the surviving $T$. absoluta population. The overall results of the present investigation after three spraying presented in (Table 20.4) revealed that among the entomopathogenic agents $H$. bacteriophora at $2,00,000 \mathrm{IJ}^{\prime}$ s/cm ${ }^{2}$ proved to be consistently effective against $T$. absoluta by recording a least larval population ( 1.64 Larvae/plant). The treatment with $H$. bacteriophora at 4,00,000 IJ's/cm ${ }^{2}$ and $S$. feltiae at $1,00,000 \mathrm{IJ}$ 's $/ \mathrm{cm}^{2}, S$. feltiae at $2,00,000 \mathrm{IJ}$ 's $/ \mathrm{cm}^{2}$ also showed better results against $T$. absoluta.

Table 2.

Efficacy of entomopathogenic nematode against Tuta absoluta in tomato crop (overall effect of three sprays).

\begin{tabular}{|c|c|c|c|c|c|c|c|c|c|c|c|c|c|c|c|c|c|c|}
\hline \multirow{4}{*}{; } & \multirow{4}{*}{$\begin{array}{l}\text { Treatments } \\
\text { /(Isolates) }\end{array}$} & \multirow{4}{*}{$\begin{array}{l}\text { EPNs } \\
\text { Dose } \\
\text { IJs } / \mathrm{m}^{-2}\end{array}$} & \multirow{4}{*}{$\begin{array}{c}\text { Pre } \\
\text { count }\end{array}$} & \multicolumn{4}{|c|}{$1^{\text {st }}$ Spray } & \multirow{4}{*}{ Mean } & \multirow{2}{*}{\multicolumn{4}{|c|}{$\begin{array}{l}2^{\text {nd }} \text { Spray } \\
\text { urvival population of } T \text {. } \\
\text { soluta larvae/plant }\end{array}$}} & \multirow{4}{*}{ Mean } & \multirow{2}{*}{\multicolumn{4}{|c|}{$\begin{array}{l}3^{\text {rd }} \text { Spray } \\
\text { urvival population of } T \text {. } \\
\text { oluta larvae/plant }\end{array}$}} & \multirow{4}{*}{ Mean } \\
\hline & & & & \multicolumn{4}{|c|}{$\begin{array}{c}\text { Mean survival population of } T \text {. } \\
\text { absoluta larvae/plant }\end{array}$} & & & & & & & & & & & \\
\hline & & & & 3 DAS & 7 DAS & 10 & 14 & & 3 DAS & $7 \mathrm{DAS}$ & 10 & 14 & & 3 DAS & 7 DAS & 10 & 14 & \\
\hline & & & & & & DAS & DAS & & & & DAS & DAS & & & & DAS & DAS & \\
\hline & S. feltiae (HR1) & $1,00,000$ & 05.77 & 02.41 & 02.16 & 01.72 & 01.59 & 01.97 & 02.15 & 01.92 & 01.79 & 01.51 & 01.84 & 02.66 & 01.70 & 01.63 & 01.34 & 01.83 \\
\hline & & & $(02.60)$ & (01.84) & (01.77) & (01.64) & (01.60) & (01.71) & (01.77) & (01.70) & (01.67) & (01.58) & (01.68) & (01.91) & (01.64) & (01.62) & (01.53) & (01.67) \\
\hline & S. feltiae (HR1) & $2,00,000$ & 06.52 & 02.67 & 02.36 & 02.05 & 01.68 & 02.19 & 02.12 & 02.10 & 01.80 & 01.38 & 01.85 & 01.83 & 01.76 & 01.64 & 01.17 & 01.60 \\
\hline & & & (02.74) & (01.91) & (01.83) & (01.74) & (01.63) & (01.77) & (01.76) & (01.76) & (01.67) & (01.54) & (01.68) & (01.68) & (01.66) & (01.62) & (01.47) & (01.60) \\
\hline & S. feltiae (HR1) & $4,00,000$ & 06.90 & 02.74 & 02.40 & 02.34 & 02.07 & 02.38 & 02.17 & 02.12 & 02.12 & 01.83 & 02.06 & 01.58 & 01.74 & 01.77 & 01.53 & 01.65 \\
\hline & & & $(02.80)$ & (01.93) & (01.84) & $(01.82)$ & (01.75) & (01.83) & (01.78) & (01.76) & (01.76) & (01.68) & (01.74) & $(01.60)$ & (01.65) & (01.66) & (01.59) & (01.62) \\
\hline & $H$. & $1,00,000$ & 07.20 & 02.317 & 02.06 & 01.44 & 01.31 & 01.78 & 01.87 & 01.56 & 01.77 & 01.45 & 01.66 & 02.59 & 02.31 & 02.12 & 01.98 & 02.25 \\
\hline & & & (02.85) & $(01.82)$ & (01.75) & (01.56) & (01.51) & (01.66) & (01.69) & $(01.60)$ & (01.66) & (01.56) & (01.62) & (01.89) & (01.82) & (01.76) & (01.72) & (01.79) \\
\hline & & & (02.73) & (01.89) & (01.78) & (01.68) & (01.55) & (01.72) & (01.65) & (01.67) & (01.63) & (01.47) & (01.60) & (01.62) & (01.56) & (01.49) & (01.44) & (01.52) \\
\hline & $H$. & $4,00,000$ & 06.21 & 02.64 & 02.26 & 02.14 & 02.13 & 02.29 & 01.74 & 01.83 & 02.05 & 01.48 & 01.77 & 01.41 & 01.17 & 01.08 & 01.02 & 01.17 \\
\hline & & & (02.68) & (01.90) & (01.80) & (01.77) & (01.76) & (01.80) & (01.65) & (01.68) & (01.74) & (01.57) & (01.66) & (01.55) & (01.42) & (01.44) & (01.42) & (01.45) \\
\hline & Control & Water & 07.36 & 03.53 & 03.87 & 04.08 & 04.09 & 03.89 & 03.79 & 04.03 & 04.28 & 04.24 & 04.08 & 04.16 & 04.23 & 04.61 & 04.92 & 04.48 \\
\hline & & Spray & (02.88) & (02.12) & $(2.20)$ & (02.25) & (02.25) & (02.20) & (02.19) & (02.24) & (02.29) & (02.28) & (02.25) & (02.27) & (02.28) & (02.37) & (02.43) & (02.33) \\
\hline & $\mathrm{SE} \pm$ & & $\mathrm{N} / \mathrm{A}$ & 0.02 & 0.01 & 0.04 & 0.05 & & 0.007 & 0.01 & 0.01 & 0.01 & & 0.02 & 0.02 & 0.02 & 0.01 & \\
\hline & $\mathrm{CD}$ at $5 \%$ & & 0.08 & 0.06 & 0.05 & 0.14 & 0.16 & & 0.02 & 0.05 & 0.05 & 0.05 & & 0.07 & 0.07 & 0.06 & 0.05 & \\
\hline
\end{tabular}

DAS = Days after spray

*Figures in parentheses are transformed values Öx+ 0.5 


\section{Discussion}

In this study it is evident that $S$. feltiae and $H$. bacteriophora were able to kill Tuta absoluta larvae at various concentrations namely $1,00,000,2,00,000$ and $4,00,000 \mathrm{lJs} / \mathrm{cm}^{2}$. Tuta absoluta larvae mortality increased with increase in concentrations. In this case the highest concentration tested $\left(4,00,000 \mathrm{IJs} / \mathrm{cm}^{2}\right)$ achieved the highest mortality under poly-house conditions. This mortality increase with increase in concentration can be attributed to large population of symbiotic bacteria released by EPNs when they penetrate the larvae as reported by (Eleftherianos et al. 2010; Han et al., 2019). Steinernematid IJs retain Xenorhabdus symbionts within an intestinal vesicle, while Photorhabdus cells stick together in the anterior part of the Heterorhabditids gut and releases them upon invasion of an insect host (Dillman et al. 2012; Lankin et al., 2021).

The third instar larvae were used; other studies revealed that EPNs were able to find and kill all the four larval instars inside or outside the leaf galleries (Batalla-Carrera et al., 2010; Van Damme et al., 2016; kasi et al., 2021). Found that T. absoluta larval stage was the most vulnerable to EPNs (Batalla-Carrera et al., 2010; Ben Husin and Port, 2021). They thus emphasized the necessity to apply EPNs on the above-ground part of the tomato plant to ensure effective control of this pest using the most suitable isolates against a particular pest in a given environment (Abbas et al., 2021; Mansour and Biondi, 2021).

The ability of EPNs to reach and kill T. absoluta larvae in leaf galleries was also reported (Batalla-Carrera et al., 2010; Van Damme et al., 2016; Kamali et al., 2018). The local EPN isolates were able to kill T. absoluta and had even been found to be effective against white grubs in Rwanda (Kajuga et al., 2018; Ndereyimana et al., 2019), while it was not easy to find EPNs which can kill them (Laznik et al., 2015). Although EPNs live naturally in soil, different researchers found that they can be used on above-ground parts of the plant to control effectively the pests living in cryptic habitats like in leaf galleries (Batalla-Carrera et al., 2010; Garcia-del-Pino et al., 2013; Lankin et al., 2021), which concurs with the results of the present study under laboratory conditions.

The IJs multiply quickly and kill the host $24-72 \mathrm{~h}$ after infection (Gozel and Kasap 2015; Van Damme et al., 2016; Kasi et al., 2021). This was verified in the present study where all local EPN isolates caused between 53.3 and $96.7 \%$ mortality just within the first $24 \mathrm{~h}$ after inoculation, while in $72 \mathrm{~h}$, they all had caused between 96.3 and $100 \%$ mortality. This is not the case of other entomopathogens like entomopathogenic fungi, which require $3-5$ days or even more time to kill their host (Reda and Hatem 2012; Abbas et al., 2021).

Different pathogenicity levels displayed by the studied EPNs agree with other studies, using different EPN isolates (Gozel and Kasap 2015; Van Damme et al., 2016; Han et al., 2019). This underlines the necessity of EPNs screening and selection as emphasized (Sharma et al., 2011; Biondi et al., 2018), in a view to boost their efficacy of EPNs. The highest efficacy of local EPN isolates than the exotics could be explained by the fact that these EPNs (Yan et al., 2016; Kasi et al., 2021; Mansour and Biondi, 2021) and they might be more adapted to the local conditions than the exotics, which were isolated in a completely different environment. These results agree with the earlier findings where locally isolated biological control agents, including EPNs, performed better than exotics (Lima et al., 2017; Nouh, 2021). The larvae of T. absoluta present susceptibility to EPNs, unlike their pupae, which present tolerance and thus a low mortality rate of less than 20\% caused by EPNs (Batalla-Carrera et al., 2010; Garcia-del-Pino et al., 2013; Ben Husin and Port, 2021; Kasi et al., 2021).

The results of this study revealed that local EPN isolates were able to find and kill $T$. absoluta larvae stages inside the leaf galleries under laboratory conditions and their efficacy increased with exposure time. The efficacy of local indigenous EPN isolates was significantly superior to that of the exotic species. This is the first study carried out in Rajghar on the good biocontrol potential of indigenous strains (HR1 and HR2) EPNs against T. absoluta. The results of this study form the basis for further research. High EPN efficacy obtained under laboratory conditions cannot easily be extrapolated to field efficacy. Therefore, future field experiments on tomato crops are justified to fully determine the potential of local EPN isolates against $T$. absoluta in Himachal Pradesh conditions.

\section{List Of Abbreviations}

EPN: Entomopathogenic nematodes; IJs: Infective juveniles; OPSTAT: Operational Status

\section{Declarations}

\section{Credit authorship contribution statement}

All authors jointly designed the experiment. KI conducted the laboratory bioassays, performed data analysis and drafted the manuscript with inputs from all authors. MS, MW and PS collaborated closely with $\mathrm{KI}$ in the whole process especially during data analysis. All authors read and approved the final manuscript.

\section{Declaration of Competing Interest}

The authors declare that they have no known competing financial interests or personal relationships that could have appeared to influence the work reported in this paper.

\section{Acknowledgements.}

We would like to acknowledge the Dr. Yashwant Singh Parmar University of Horticulture and Forestry, Nauni, Solan, HP, India-173230 for support of this research. And Indian council of Agricultural Research (ICAR) for providing necessary facilities and financial support, respectively We are also grateful to Department of entomology, Nematology laboratory used in this study.

\section{Availability of data and materials}

The datasets used and analysed during the current study are available from the corresponding authors on reasonable request. 


\section{Consent for publication}

All authors agree to the publication of the submitted manuscript.

\section{References}

Abbas W, Javed N, Haq IU, Ahmed S (2021) Pathogenicity of entomopathogenic nematodes against cabbage butterfy (Pieris brassicae) Linnaeus (Lepidoptera: Pieridae) in laboratory conditions. Int J Trop Insect Sci 41:525-531. https://doi.org/10.1007/s42690-020-00236-2

Abbott WS (1925) A method of computing the effectiveness of an insecticide. J Econ Entomolo 18: 265-267.

Arthurs S, Heinz KM, Prasifka JR (2004) An analysis of using entomopathogenic nematodes against above-ground pests. Bulletin of Entomological Research 94: 297-306. https://doi.org/10.1079/BER2003309

Ballal CR, Gupta A, Mohan M, Lalitha Y, Verghese A (2016) The new invasive pest Tuta absoluta (Meyrick) (Lepidoptera: Gelechiidae) in India and its natural enemies along with evaluation of Trichogrammatids for its biological control. Curr Sci, 110, 2155-2159. https://doi.org/10.18520/cs/v110/i11/2155-2159.

Barati R, Hejazi MJ, Mohammadi SA (2018) Insecticide susceptibility in Tuta absoluta (Lepidoptera: Gelechiidae) and metabolic characterization of resistance to diazinon. J Econ Entomol 111:1551-1557. https://doi.org/10.1093/jee/toy134

Batalla-Carrera L, Morton A, Garcia-del-Pino F (2010) Efficacy of entomopathogenic nematodes against tomato leafminer Tuta absoluta in laboratory and greenhouse conditions. Bio Control I55:523-530. https://doi.org/10.1007/s10526-010-9284-z

Ben Husin TO, Port GR (2021) Efficacy of entomopathogenic nematodes against Tuta absoluta. Biological Control 160, 104699. https://doi.org/10.1016/j.biocontrol.2021.104699

Biondi A, Guedes RNC, Wan FH, Desneux N (2018) Ecology, worldwide spread, and management of the invasive South American tomato pinworm, Tuta absoluta: past, present, and future. Annu Rev Entomol 63:239-258. https://doi.org/10.1146/annurev-ento-031616-034933

Biondi A, Desneux N (2019) Special issue on Tuta absoluta: recent advances in management methods against the background of an ongoing worldwide invasion. Journal of Pest Science 92:1313-1315. https://doi.org/10.1007/s10340-019-01132-6

Bird AF, Akhurst RJ (1983) The nature of the intestinal vesicle in nematodes of the family Steinernematidae. Int J of Parasit 13: 599606. https://doi.org/10.1016/S0020-7519(83)80032-0

CABI (2020) Invasive Species Compendium, Wallingford. https://www.cabi.org/isc. Accessed 26 Oct 2020.

CABI (2018) Tuta absoluta. In: Invasive Species Compendium. Wallingford, UK: CAB International. Retreived from: www.cabi.org/isc.

Campos MR, Biondi A, Adiga A, Guedes RNC, Desneux N (2017) From the Western Palaearctic region to beyond: Tuta absoluta 10 years after invading Europe. Journal of Pest Science 90: 787-796. https://doi.org/10.1007/s10340-017-0867-7

Desneux N, Wajnberg E, Wyckhuys KAG, Burgio G, Arpaia S, Narvaez-Vasquez CA, Gonzalez-Cabrera J, Ruescas DC, Tabone E, Frandon J, Pizzol J, Poncet C, Cabello T, Urbaneja A (2010) Biological invasion of European tomato crops by Tuta absoluta: ecology, geographic expansion and prospects for biological control. J Pest Sci 83:197-215. https://doi.org/10.1007/s10340-010-0321-6.

Dillman AR, Chaston JM, Adams BJ, Ciche TA, Goodrich-Blair H, Stock SP, Steinberg PW (2012) An entomopathogenic nematode by any other name. pLos pathog 8: e1002527.

Dowds BCA, Peters A (2002) Virulence mechanisms. In: Gaugler, R. (Ed.), Entomopathogenic Nematology. CABI Publishing, New York, USA, pp. $79-98$.

Eleftherianos I, Joyce S, French-Constant RH, Clarke DJ, Reynolds SE (2010) Probing the tri-trophic interaction between insects, nematodes and Photorhabdus. Parasitology 137: 1695-1706. https://doi.org/10.1017/S0031182010000508

Finney DJ (1971) Statistical Analysis. Cambridge University Press.

Forst S, Clarke D (2002) Bacteria-nematode symbiosis. In: Gaugler, R. (Ed.), Entomopathogenic Nematology. CABI Publishing, New York, USA, pp. 57-77.

Garcia-del-Pino F, Alabern X, Morton A (2013) Efficacy of soil treatments of entomopathogenic nematodes against the larvae, pupae and adults of Tuta absoluta and their interaction with insecticides used against this insect. Bio Control 58:723-731. https://doi.org/10.1007/s10526-013-9525-z.

Gozel C, Kasap I (2015) Efficacy of entomopathogenic nematodes against the Tomato leafminer, Tuta absoluta (Meyrick) (Lepidoptera: Gelechiidae) in tomato field. Turk Entomol Derg 39:229-237. https://doi.org/10.16970/ted.84972.

Grewal PS, Ehlers RU, Shapiro-llan DI (2005) Nematodes as Biocontrol Agents. CABI Publishing, Wallingford, UK.

Han P, Bayram Y, Shaltiel-Harpaz L, Sohrabi F, Saji A, Esenali UT, Jalilov A, Ali A, Shashank PR, Ismoilov K, Lu Z-Z, Wang Su, Zhang GF, Wan FH, Biondi A, Desneux N 2019. Tuta absoluta continues to disperse in Asia: damage, ongoing management and future challenges. J. Pest Sci. 92 (4), 1317-

Page $9 / 13$ 
Head J, Lawrence AJ, Walters KFA (2004) Efficacy of the entomopathogenic nematode, Steinernema feltiae, against Bemisia tabaci in relation to plant species. J of Appl Entomol 128: 543-547. https://doi.org/10.1111/j.1439-0418.2004.00882.x

ICAR (2015): Tuta absoluta: A New Invasive Pest Alert, New Delhi, India: Indian Council for Agricultural Research. - http://www.icar.org.in/en/node/8600

Ingegno BL, Feracini C, Gallinotti D, Alma A, Tavella L (2013) Evaluation of the effectiveness of Dicyphus errans (Wolff) as predator of Tuta absoluta (Meyrick). Biol Control 67: 246-52. https://doi.org/10.1016/j.biocontrol.2013.08.002.

Kajuga J, Hategekimana A, Yan X, Waweru BW, Li H, Li K (2018) Management of white grubs (Coleoptera: Scarabeidae) with entomopathogenic nematodes in Rwanda. Egypt J Biol Pest Co 28:2. https://doi.org/10.1186/s41938-017-0003-2

Kalleshwaraswamy CM, Murthy S, Viraktamath CA, Krishna NK (2015) Occurrence of Tuta absoluta (Lepidoptera: Gelechiidae) in the Malnad and HyderabadKarnataka regions of Karnataka, India. Fla Entomol 98: 970-971. https://doi.org/10.1653/024.098.0326.

Kamali S, Karimi J, Koppenhofer AM (2018) New Insight into the Management of the Tomato Leaf Miner, Tuta absoluta (Lepidoptera: Gelechiidae) with Entomopathogenic Nematodes. J Econ Entomol 111:112-119. https://doi.org/10.1093/jee/tox332.

Kasi IK, Singh M, Waiba KM, Monika S, Waseem MA, Archie D, Gilhotra H (2021) Bio-efficacy of entomopathogenic nematodes, Steinernema feltiae and Heterorhabditis bacteriophora against the Cabbage butterfly (Pieris brassicae [L.]) under laboratory conditions. Egypt J Biol Pest Control, 31:125. https://doi.org/10.1186/s41938-021-00469-4

Kaya HK, Gaugler R (1993) Entomopathogenic nematodes. Annual Review of Entomology 38: 181206. https://doi.org/10.1146/annurev.en.38.010193.001145

Lankin G, Santiagos A, Hermosilla M, Aballay E, San-Blas E, (2021) A novel approach for the biological control of invasive Bagrada bugs with entomopathogenic nematodes. Journal of Pest Science, https://doi.org/10.1007/s10340-021-01400-4

Laznik Z, Trdan S (2015) Failure of entomopathogens to control white grubs (Coleoptera: Scarabaeidae). Acta Agric Scand 65:95108. https://doi.org/10.1080/09064710.2014.968199

Lewis EE, Campbell JC, Griffn C, Kaya HK, Peters A (2006) Behavioral ecology of entomopathogenic nematodes. Biolog Control 38: 6679. https://doi.org/10.1016/j.biocontrol.2005.11.007

Lietti MM, Botto E, Alzogaray RA (2005) Insecticide resistance in Argentine populations of Tuta absoluta (Meyrick) (Lepidoptera: Gelechiidae). Neotrop Entomol 34:113-119. https://doi.org/10.1590/S1519-566X2005000100016

Lima MD, Pascual PRL, Alburo HMA (2017) Heterorhabditis taysearae and Heterorhabditis bacteriophora: Promising Indigenous. J Agri Tech Manag 20:813. http://jatm.ctu.edu.ph/index.php/jatm/article/view/187

Mansour R, Biondi A (2021) Releasing natural enemies and applying microbial and botanical pesticides for managing Tuta absoluta in the MENA region. Phytoparasitica 49: 179-194. https://doi.org/10.1007/s12600-020-00849-w.

Martens EC, Goodrich-Blair H (2005) The Steinernema carpocapsae intestinal vesicle contains a sub-cellular structure with which Xenorhabdus nematophila associates during colonization initiation. Cellular Microbiology 7: 1723-1735. https://doi.org/10.1111/j.1462-5822.2005.00585.x

Martens EC, Vivas El, Heungens K, Cowles CE, Goodrich-Blair H (2004) Investigating mutualism between entomopathogenic bacteria and nematodes. Nematology Monographs and Perspectives: Proceedings of the Fourth International Congress on Nematology 2: 447-462.

Morton A, Garcia-del-Pino F (2009) Ecological characterization of entomopathogenic nematodes isolated in stone fruit orchard soils of Mediterranean areas. J of Invert Patholo 102: 203-213. https://doi.org/10.1016/j.jip.2009.08.002

Ndereyimana A, Nyalala S, Murerwa P, Gaidashova S (2019) Potential of entomopathogenic nematode isolates from Rwanda to control the tomato leaf miner, Tuta absoluta (Meyrick) (Lepidoptera: Gelechiidae). Egypt. J. Biol. Pest Co 29: 57. https://doi.org/10.1186/s41938-019-0163-3.

Ndereyimana A, Nyalala S, Murerwa P, Gaidashova S (2020) Field efficacy of entomopathogens and plant extracts on Tuta absoluta Meyrick (Lepidoptera: Gelechiidae) infesting tomato in Rwanda. Crop Protection, 105183. https://doi.org/10.1016/j.cropro.2020.105183

Nouh GH (2021) Efficacy of the entomopathogenic nematodes isolates against Spodoptera littoralis (Boisduval) and Agrotis ipsilon (Hufnagel) (Lepidoptera: Noctuidae). Egypt J Biol Pest Control 31:1-5. https://doi.org/10.1186/s41938-021-00374-w

Poinar GO (1990) Biology and taxonomy of Steinernematidae and Heterorhabditidae. In: Gaugler R, Kaya HK (eds) Entomopathogenic nematodes in biological control. CRC Press, Boca Raton, pp 23-58.

Reda AM, Hatem AE (2012) Biological and eradication parameters of the tomato leaf miner, Tuta absoluta (Meyrick) (Lepidoptera: Gelechiidae) affected by two biopesticides. Bol San Veg Plagas 38:321-333. 
Roditakis E, Skarmoutsou C, Staurakaki M, Martinez-Aguirre MR, Garcia-Vidal L, Bielza P, Haddi K, Rapisarda C, Rison JL, Bassi A, Teixeira LA (2013) Determination of baseline susceptibility of European populations of Tuta absoluta (Meyrick) to indoxacarb and chlorantraniliprole using a novel dip bioassay method. Pest Manag Sci 69:217-227. https://doi.org/10.1002/ps.3442.

Roditakis E, Vasakis EA, Grispou M, Stavrakaki M, Nauen R, Gravouil M, Bassi A (2015). First report of Tuta absoluta resistence to diamide insecticides. J Pest Sci, 88: 9-16. https://doi.org/10.1007/s10340-015-0643-5

Shapiro-llan D, Han, R, Qiu, X (2014) Production of entomopathogenic nematodes. In: Morales-Ramos, J., Rojas, G., Shapiro-llan, D.I. (Eds.), Mass Production of Beneficial Organisms: Invertebrates and Entomopathogens. Academic Press, Elsevier Inc., San Diego, California, USA, pp. 321-356.

Sharma MP, Sharma AN, Hussaini SS (2011) Entomopathogenic nematodes, a potential microbial biopesticide: mass production and commercialisation status-a mini review. Arch Phytopathology Plant Protect 44: 855-870. https://doi.org/10.1080/03235400903345315

Sharma PL, Gavkare O (2017) New Distributional Record of Invasive Pest Tuta absoluta (Meyrick) in North-Western Himalayan Region of India. National Academy Science Letters 40: 217-220. https://doi:10.1007/s40009-016-0526-1

Shashank PR, Chandrashekar K, Naresh MM, Sreedevi K (2015) Occurrence of Tuta absoluta (lepidoptera: gelechiidae) an invasive pest from India. Indian J Ent. 77, 323-329. https://doi.org/10.5958/0974- 8172.2015.00070.X.

Sicard M, Brugirard-Ricaud K, Pages S, Lanois A, Boemare NE, Brehelin M, Givaudan A (2004) Stages of infection during the tripartite interaction between Xenorhabdus nematophila, its nematode vector, and insect hosts. Appli and Environ Microb 70: 6473-6480. https://doi.org/10.1128/AEM.70.11.64736480.2004

Silva CP, Waterfield NR, Daborn PJ, Dean P, Chilver T, Au CPY, Sharma S, Potter U, Reynolds SE, Ffrench-Constant RH (2002) Bacterial infection of a model insect: Photorhabdus luminescens and Manduca sexta. Cell Microbiolo 4: 329-339 (2002). https://doi.org/10.1046/j.1462-5822.2002.00194.x

Sridhar V, Chakaravarthy AK, Asokan R, Vinesh LS, Rebijith KB, Vennila S (2014) New record of the invasive South American tomato leafminer, Tuta absoluta (Meyrick) (Lepidoptera: Gelechiidae) in India. Pest Manag. Hortic. Ecosyst 20:148-154.

Susurluk A (2008) Potential of the entomopathogenic nematodes Steinernema feltiae, S. weiseri and Heterorhabditis bacteriophora for the biological control of the sugar beet weevil Bothynoderes punctiventris (Coleoptera: Curculionidae). J Pest Sci 81:221-225. https://doi.org/10.1007/s10340-008-0209-x

Urbaneja A, Gonzalez-Cabrera J, Arno J, Gabarra R (2012) Prospects for the biological control of Tuta absoluta in tomatoes of the Mediterranean basin. Pest Manage Sci, 68: 1215-1222. https://doi.org/10.1002/ps.3344.

Urbaneja AR, Vercher V, Navarro F, Mari G, Porcuna JL (2008) La polilla del tomato, Tuta absoluta. Phytoma Espana, 194: 16-

23. http://hdl.handle.net/20.500.11939/4087.

Van Damme VM, Beck BK, Berckmoes E, Moerkens R, Wittemans L, De Vis R (2016) Efficacy of entomopathogenic nematodes against larvae of Tuta absoluta in the laboratory. Pest Manag Sci 72:1702-1709. https://doi.org/10.1002/ps.4195.

Waiba KM, Sharma P, Kumar KI, Chauhan S (2021) Studies of Genetic Variability of Tomato (Solanum lycopersicum L.) Hybrids under Protected Environment. International Journal of Bio-resource and Stress Management 12: 264-270. https://doi.org/10.23910/1.2021.2211.

Williams EC, Walters KFA (2000) Foliar application of the entomopathogenic nematode Steinernema feltiae against leaf miners on vegetables. Bio Sci and Techn 10: 61-70. https://doi.org/10.1080/09583150029396

Woodring JL, Kaya HK (1988) Steinernematid and heterorhabditid nematodes: a handbook of biology and techniques. Arkansas Agricultural Experiment Station, Fayetteville.

Yan X, Waweru B, Qiu X, Hategekimana A, Kajuga J, Li H (2016) New entomopathogenic nematodes from semi-natural and small-holder farming habitats of Rwanda. Bio Sci Techn 26:820-834. https://doi.org/10.1080/09583157.2016.1159658.

\section{Figures}

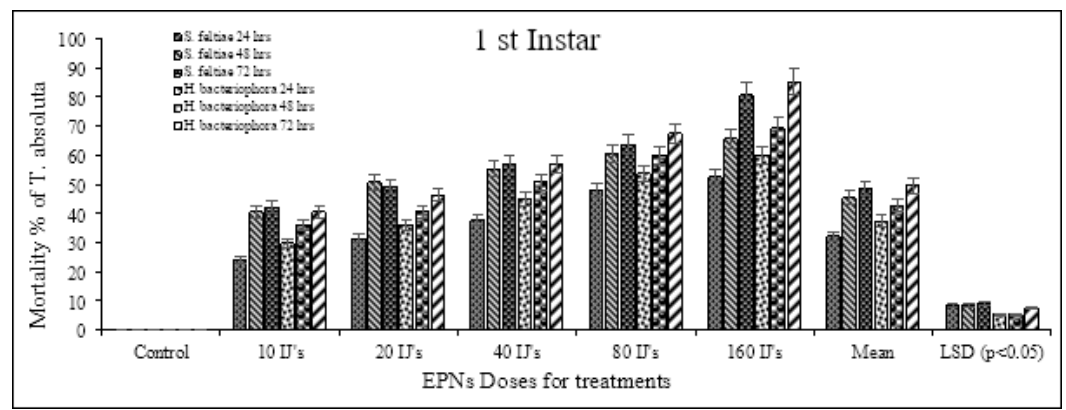

Page $11 / 13$ 
Figure 1

Efficacy of $S$. feltiae and $H$. bacteriophora against $1^{\text {st }}$ instar of $T$. absoluta

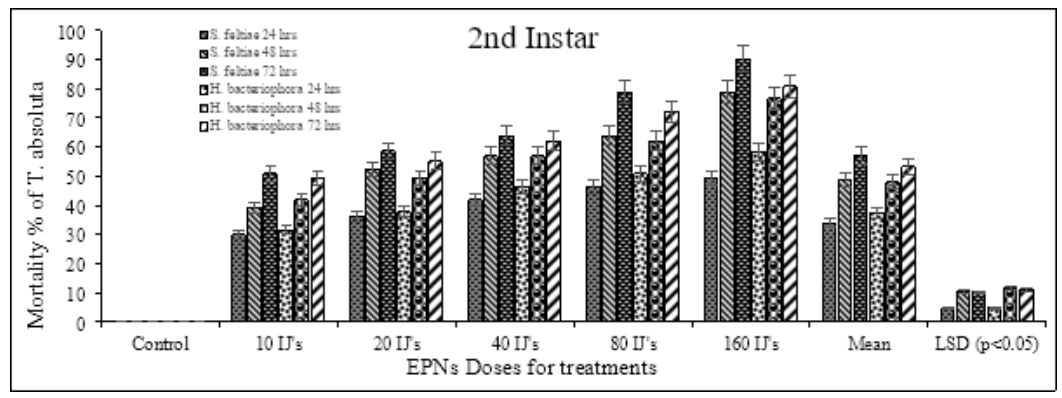

Figure 2

Efficacy of S. feltiae and H. bacteriophora against $2^{\text {nd }}$ instar of $T$. absoluta

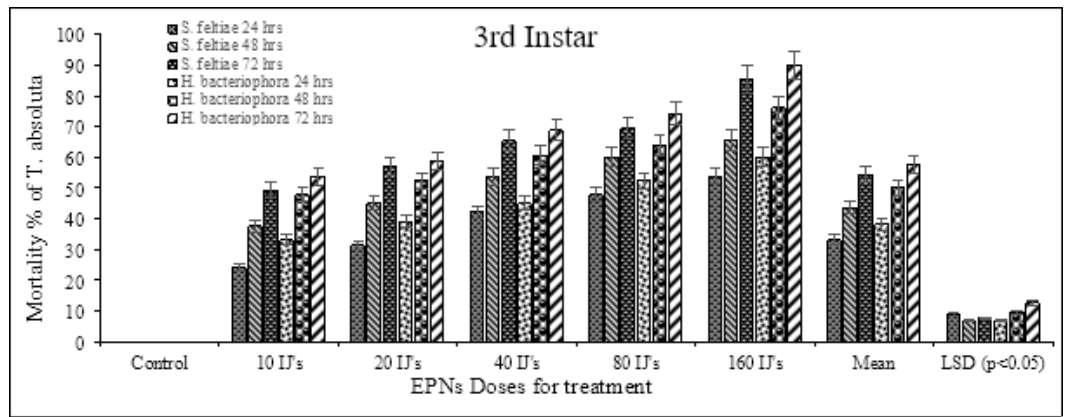

Figure 3

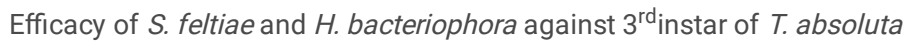

Figure 4

Efficacy of $S$. feltiae and H. bacteriophora against $4^{\text {th }}$ instar of $T$. absoluta

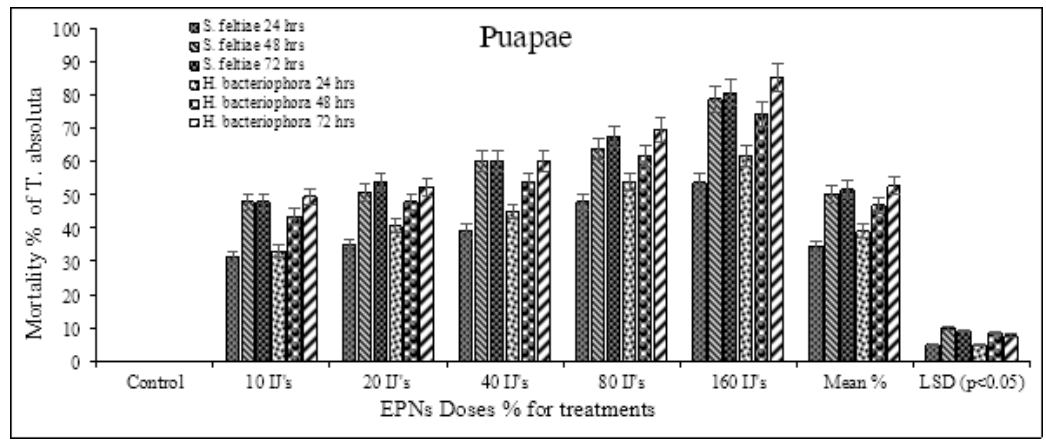

Figure 5

Efficacy of S. feltiae and H. bacteriophora against pupae of T. absoluta 


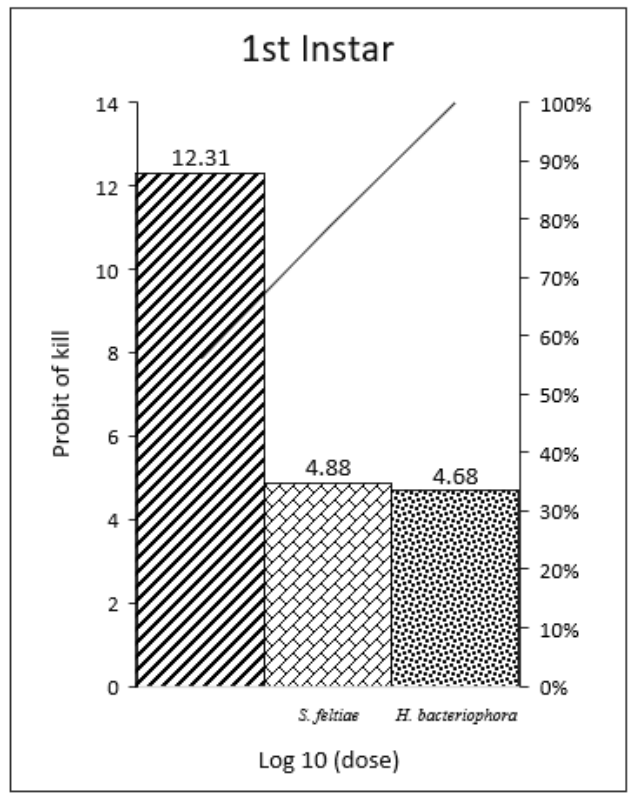

Figure 6

$1^{\text {st }}$ instar Log Dose response Curve

Figure 7

$2^{\text {nd }}$ instar Log Dose response Curve

Figure 8

$3^{\text {rd }}$ instar Log Dose response Curve

Figure 9

$4^{\text {th }}$ instar Log Dose response Curve

Figure 10

Pupae log Dose response Curve 